\title{
PARCIÁLIS NYOMÁSOK MÉRÉSÉRE ALKALMAS BEÁGYAZOTT RENDSZER FEJLESZTÉSE REAKTÍV PORLASZTÓBERENDEZÉS SZÁMÁRA
}

\section{DEVELOPMENT OF AN EMBEDDED PARTIAL PRESSURE MEASURING SYSTEM FOR USE IN REACTIVE SPUTTERING SYSTEM}

\author{
Fekete Albert-Zsombor ${ }^{1}$, Jakab-Farkas László ${ }^{2}$ \\ ${ }^{l}$ S.C. Tetronic S.R.L., 547530, Románia, Marosszentgyörgy, Wesselényi Erzsébet ut- \\ ca 6 szám; Tel.+40-766-649950, levelezési cím: zsombor.fekete@tetronic.ro \\ ${ }^{2}$ Sapientia Erdélyi Magyar Tudományegyetem, Müszaki és Humántudományok Kar, \\ 540485, Románia, Marosvásárhely, Segesvári út 1C; Tel. +40-745-873844, levele- \\ zési cím: jflaci@ms.sapientia.ro
}

\begin{abstract}
The reactive magnetron sputtering process is used to obtain thin film coatings utilized in industrial applications, medicine, aerospace, exploiting their versatile structural and chemical properties. The application field of the layers is determined by their composition and structure, which determine their properties. At the International Physics Research Institute from the Faculty of Technical and Human Sciences of Sapientia Hungarian University of Transilvania wear-resistant thin film coatings are studied and produced with reactive magnetron sputtering method. In order to have a reproducible process, it is necessary to have a controlled environment, which is achieved by developing different monitoring and control systems. The main purpose of this article is to present the design process of an embedded system that enables the control of the quadrupole mass analyzer and its connection to the internal ethernet network of the laboratory, as well as the development of the different algorithms for the distributed system. With the help of this equipment it is possible to measure the partial pressures of the different inert and reactive gases used in the sputtering process.
\end{abstract}

Keywords: thin film coating, partial pressure, quadrupole mass spectrometer, embedded system

\section{Összefoglalás}

A reaktív egyenáramú magnetronos porlasztási eljárás segítségével számos vékonyréteg-bevonat hozható létre, amelyek felhasználhatóak különféle ipari alkalmazásokban, az orvostudományban, a repülöiparban, kamatoztatva sokoldalú szerkezeti és kémiai tulajdonságaikat. Az alkalmazási területet egyértelmủen a rétegek összetétele és szerkezete határozza meg. Annak érdekében, hogy a porlasztási folyamat stabil és megismételhető legyen, szükségessé válik a folyamat valamennyi paraméterének szabályozása, amely testre szabott mérö, adatgyüjtő és irányítási rendszerek fejlesztésével érhető el. A következő cikk fö célja ismertetni a tervezési és megvalósítási lépéseit annak a beágyazott rendszernek, amely vezérel egy kvadrupól tömegspektrométert, valamint lehetővé teszi az analizátor által mért adatok elérését a laboratórium ethernet alapú belső hálózatán keresztül. A megvalósított rendszer segítségével lehetőség nyílik a reaktív porlasztási folyamatban részt vevő semleges és reaktív gázok parciális nyomásainak mérésére.

Kulcsszavak: vékonyréteg, parciális nyomás, kvadrupól analizátor, beágyazott rendszer 


\section{Bevezető}

A Sapientia Erdélyi Magyar Tudományegyetem Műszaki és Humántudományok Karán belül müködö Nemzetközi Fizika Kutatóintézetben kopásálló vékonyréteg-bevonatok előállításával és tanulmányozásával foglalkoznak. A reaktív egyenáramú magnetronos porlasztási eljárással elöállított titán-nitrid $\left(\mathrm{Ti}_{\mathrm{x}} \mathrm{N}_{\mathrm{y}}\right)$ és titánoxinitrid $\left(\mathrm{TiO}_{\mathrm{x}} \mathrm{N}_{\mathrm{y}}\right)$ vékonyrétegek elsősorban az intenzív súrlódásnak kitett ipari berendezések alkatrészeinek élettartamát hivatottak növelni.

A sikeres és megismételhető, komplex porlasztási folyamat alapfeltétele a rendszer valamennyi paraméterének (porlasztási teljesítmény, rétegnövekedési sebesség, gázhozamok, dinamikus és parciális nyomások) szabályozása. Ezen folyamat rendszerint saját tervezésü, testre szabott mérö és irányítási rendszerek, algoritmusok, elektronikai áramkörök kidolgozását és megvalósítását feltételezi.

\section{Célkitűzés}

A folyamat során használt semleges argongáz, valamint a reaktív nitrogén- és oxigéngázok a porlasztóberendezésben parciális nyomásokat hoznak létre. A reaktív gázok egy adott része részt vesz a reakcióban és beépül a rétegbe [3]. Bár vezérelt hozamszabályozók használata révén a beengedett gázmennyiség ismert és állandó, a folyamat többi paraméterének változása következtében a reaktív gázok parciális nyomásai a folyamat során változnak. Ez természetesen egy nem kívánt jelenség, mivel a parciális nyomás változása hatással van a réteg szerkezetére.

A cél egy olyan irányítási rendszer kifejlesztése, melynek segítségével a reaktív gázok parciális nyomásai szabályozhatóak, s ezáltal lehetőség nyílik az állandó rétegszerkezet elérése is. Megvalósításának első lépése egy mérőrendszer építését feltételezi, melynek segítségével elvégezhető a parciális nyomások folyamat közbeni mérése. A használt analizátor egy kvadrupól típusú tömegspektrométer, melynek aktív pásztázási tartománya 0-99 atomtömegegység (Da). Az analizátor ionizálja a gázt, majd elektromos tér segítségével szétválasztja az ionokat a tömegtöltésük $(\mathrm{m} / \mathrm{z})$ függvényében [1-2]. Továbbá megadható a mérési érzékenység és felbontás is, melyek függvényében változik a pásztázási idő is pár másodperc és 1-2 perc között. Minél nagyobb a felbontás, annál tovább tart egy teljes mérés. A megengedett, biztonságosan használható nyomástartomány felső határa $10^{-9}$ Torr. Egy teljes pásztázás eredménye atomtömegegység és Torrban kifejezett parciális nyomás típusú adatpárokból épül fel.

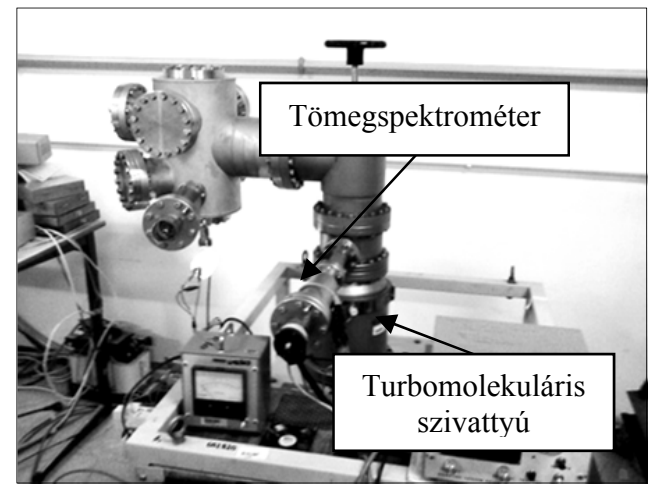

1. ábra. Kisérleti berendezés: kvadrupól tömegspektrométer (QMS) saját vákuumkamrával, turbomolekuláris szivattyúval és vészleállitó áramkörrel

\section{Beágyazott rendszer fejlesztése}

A beágyazott rendszer alapvető feladata egy stabilan müködő, megbízható platform biztosítása a különböző irányítási, adatfeldolgozó és adattovábbítási algoritmusok számára, melyeknek köszönhetően egy könnyedén paraméterezhető és kezelhető mérőrendszert kapunk. 
A beágyazott rendszer, melynek leegyszerüsített elvi tömbrajza a 2. ábrán látható, két mikrovezérlöre épül, amelyek jól meghatározott és elkülönített feladatokat látnak el.

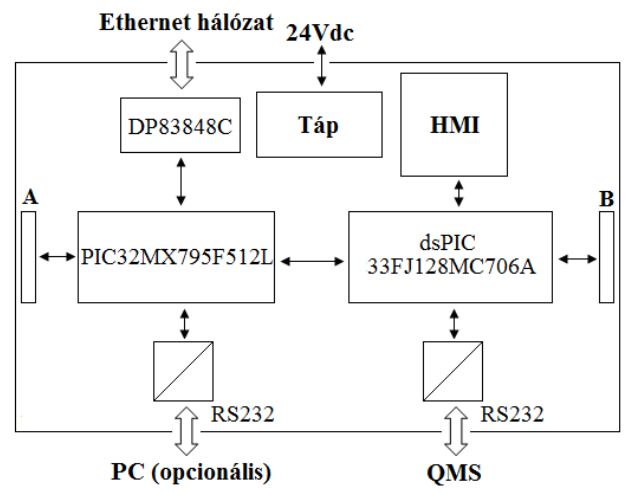

2. ábra. Beágyazott rendszer leegyszerüsitett elvi tömbrajza

Egy DSP típusú, 16 bittes architektúrájú mikrovezérlő gondoskodik a tömegspektrométer összes időkritikus irányítási és számításigényes adatfeldolgozási algoritmusainak a végrehajtásáról. Másodlagos feladata egy helyi ember-gép interfész (HMI) müködtetése.

A HMI révén helyileg ellenőrizhetőek a tömegspektrométer paraméterei, a rendszer aktuális állapota, valamint az ethernet típusú hálózati csatlakozás beállításai (MAC cím, IP cím).

A második, 32 bittes architektúrájú mikrovezérlő alapvető feladata biztosítani az adatforgalmat a különböző kommunikációs interfészek között, feldolgozni a beérkező utasításokat és kiszolgálni a kéréseket. Az ethernet alapú hálózaton TCP csomagok formájában történik az adatok kétirányú küldése, továbbá egy beágyazott web-szervernek köszönhetően böngészőn keresztül is elérhetjük a tömegspektrométert bármilyen mobil platformról. A különböző algoritmusok helyes működését az együtt- müködő többfeladatos feldolgozás (,cooperative multitasking”) biztosítja [4].

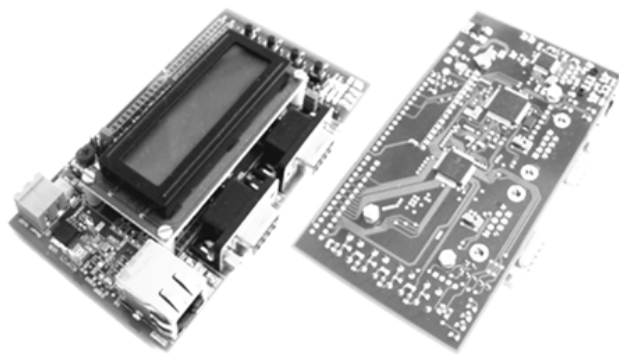

3. ábra. A megvalósitott mikrovezérlös beágyazott rendszer

A nyomtatott áramkör tervezésének egyik alapkövetelménye a zajimmunitás biztosítása, valamint a $100 \mathrm{Mbit} / \mathrm{s}$ adatátviteli sebességre alkalmas ethernet interfész alkatrészeinek kompakt elrendezése. A zajimmunitás lokális EMI/EMC szürők, ferrités alacsony impedanciás tantál- vagy kerámiakondenzátorból felépülő LC szürők segítségével érhető el. A rendszerben megjelenő, $\mathrm{kHz}$ tartományban levő zajok elsődleges forrásai a porlasztási folyamatban használt, nagy teljesítményü kapcsolóüzemü tápegységek.

A négyrétegü nyomtatott áramkör esetében a mikrovezérlők felöli közbelső, árnyékoló szerepet betöltő réteg GND potenciálra van kötve, ezáltal a fémház használata nem kötelezö.

\subsection{DMA vezérlő alkalmazása soros adatcsere hatékonyságának növe- lésére}

A hardverközeli algoritmusok és a mikrovezérlőben lévő DMA (,,Direct Memory Access") vezérlő segítségével az aszinkron soros kommunikációt kívántuk hatékonyabbá tenni azáltal, hogy függetlenítjük a processzortól a belső RAM memória és a soros periféria között zajló adatcserét [5]. A soros interfész mindössze 4Bos puffere, valamint a nagy adatforgalom indokolja a DMA vezérlö használatát. 


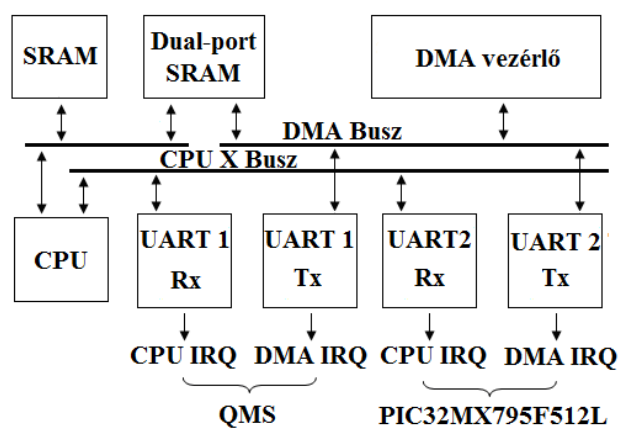

4. ábra. DSP mikrovezérlö DMA és buszrendszerének elvi tömbrajza [5]

A 4. ábrán megfigyelhető, hogy a DMA vezérlő egy saját buszon keresztül eléri a soros perifériát, valamint a dual-port RAM típusú memóriát [5]. Mivel az adatcsomagok mérete széles skálán változhat (3B$4 \mathrm{kB}$ ), csak a küldésnél használjuk a DMA vezérlőt, hiszen csak ebben az esetben ismert elöre a csomag hossza. Az adatok fogadása tehát a hagyományos, bájtonkénti csomagösszerakás módszerén alapszik.

A beágyazott rendszerben levő 40MIPSes dsPIC33FJ128MC706A mikrovezérlő esetében a DMA vezérlő és az alkalmazott algoritmusok használatával 500ns/B végrehajtási idő takarítható meg.

\subsection{Mérési eredmények}

A mérőrendszer müködésének ellenőrzésére számos próbamérést végeztünk.

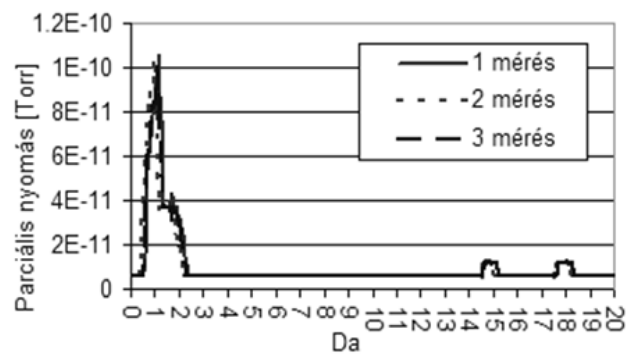

5. ábra. Próbamérés: 3 különböző pásztázás eredménye (azonos érzékenység és mérési feltételek)
A mérések több napos eltéréssel, de azonos feltételek mellett zajlottak. Minden esetben azonos volt a beállított érzékenység, valamint a mérőrendszer saját vákuumkamrájában lévő gázelegy összetétele. A mérések eredményeit az 5. ábra tartalmazza.

\section{Következtetések}

A nyomtatott áramkör tervezése során használt eljárásoknak köszönhetően a laboratóriumban megjelenő vezetett és sugárzott zajok nem befolyásolják az elektronikai áramkör müködését. Az azonos feltételek mellett történő, de időben többnapos eltéréssel elvégzett próbamérések eredményei minimális eltéréssel $(< \pm 1 \%)$ megegyeztek, ezáltal elmondhatjuk, hogy a mérőrendszer alkalmas a porlasztási folyamat során használt semleges és reaktív gázok parciális nyomásainak mérésére.

\section{Szakirodalmi hivatkozások}

[1] Dunnivant, F.M., Ginsbach, J.W.: Gas Chromatography-, Liquid Chromatography-, Capillary Electrophoresis-Mass Spectrometry - A basic introduction. Whitman College, Chemistry Department, 2011. 5.5.2 alfejezet.

[2] Dunnivant, F.M., Ginsbach, J.W.: Flame Atomic Absorbance and Emission Spectrometry and Inductively Coupled Plasma Mass Spectrometry. Whitman College, Chemistry Department, 2011. 4. fejezet.

[3] Berg, S., Nyberg, T.: Fundamental understanding and modeling of reactive sputtering processes. Science Direct, Thin Solid Films 476, 2005. 215-235.

[4] *** TCP/IP programcsalád leírása: Microchip TCP/IP Stack Help (verzió: 5.42.08-2013.).

[5]*** DMA vezérlő ismertetése dsPIC33-as mikrovezérlöre: Section 22. Direct Memory Access (DMA), Internetes elérési lehetőség: http://ww1.microchip.com/downloads/en/Dev iceDoc/70182C.pdf (2014). 